\title{
Establishment of a community managed marine reserve in the Bay of Ranobe, southwest Madagascar
}

\author{
Elise M. S. Belle ${ }^{1 *}$, Gerard W. Stewart *, Benjamin De \\ Ridder', Roberto J.-L. Komeno', Frédéric Ramahatratra', \\ Brice Remy-Zephir', and Roderick D. Stein-Rostaing
}

Correspondence:

Roderick Stein-Rostaing

14 Charlwood Terrace - Putney, London SW15 1NZ, U.K.

Phone: +44 (0)7866 250740

E-mail: reefdoctor@hotmail.com

\section{ABSTRACT}

The Bay of Ranobe, in southwest Madagascar, once noted for its high biodiversity and fish abundance, is under increasing pressure from overfishing, pollution, sedimentation and tourism. The declining health of the coral reef is reflected in fishery productivity and survey data on biological diversity.

Sustainable conservation requires the engagement of all interested parties and the integration of their needs into resource management. The British NGO ReefDoctor has adopted this approach in establishing the first community-protected site in the Bay of Ranobe, the Massif des Roses. This is a large coral patch with a high percentage of live coral cover (38\%) and important fish diversity compared to other sites surveyed in the lagoon. Since 25 May 2007 it has been legally recognised as a community managed marine reserve under temporary protection where fishing is banned. Tourists must now pay an entry fee to visit the site, with the proceeds contributing to the funding of community projects. In conjunction with the protection of this site, ReefDoctor has worked with local people, regional and local government, tour operators and hotels, and conservation organisations to set up 'FIMIHARA', an association representative of local people responsible for the management of this site and the development of sustainable conservation initiatives in the Bay of Ranobe.

This paper explains the approach taken by ReefDoctor, by setting up and working with FIMIHARA, to protect the Massif des Roses site and develop other conservation initiatives and community projects in the Bay of Ranobe.

\section{RÉSUMÉ}

La baie de Ranobe, au sud-ouest de Madagascar, autrefois remarquable pour sa biodiversité et l'abondance de la pêche, est de plus en plus menacée par la surpêche, la sédimentation, la pollution et le tourisme. Le déclin de l'état de santé du récif corallien se reflète dans la diminution de la productivité des pêcheries et dans les suivis de la biodiversité marine. La situation est à présent critique car les ressources marines associées au récif assurent la subsistance des populations côtières vivant le long de la baie.
Nous considérons ici qu'une protection pérenne nécessite un engagement concret de toutes les parties prenantes - en particulier des communautés locales - et que leurs besoins soient intégrés dans la gestion des ressources. L'ONG ReefDoctor a mis en œuvre cette approche lors de la création de la première réserve marine dans la baie de Ranobe gérée par la communauté locale, le Massif des Roses. Cette réserve est constituée d'un grand massif de corail largement couvert de coraux et abritant une importante diversité de poissons par rapport au reste du lagon. Depuis le 25 mai 2007, ce site est légalement reconnu comme réserve marine communautaire avec un statut de protection temporaire ; la pêche et les pratiques destructrices associées au tourisme y sont interdites. De plus, les touristes doivent désormais payer un droit d'entrée pour visiter le site, qui contribue au financement de projets communautaires. En parallèle avec la protection du site, ReefDoctor a travaillé avec les communautés locales, les responsables nationaux et régionaux du gouvernement, les opérateurs touristiques et diverses organisations de protection de la nature pour créer l'association FIMIHARA, représentative de la population locale. Cette association, qui a un statut légal depuis le 11 avril 2007, a pour but d'améliorer la qualité de vie de ceux qui vivent le long de la baie de Ranobe et de mettre en œuvre des projets de conservation des ressources marines et terrestres dans la région de la baie de Ranobe.

La création de la réserve marine communautaire du Massif des Roses a rapidement connu le succès qui s'est traduit par la vente de plus d'un millier de tickets, mais I'association FIMIHARA doit encore faire face à de nombreux défis. L'objectif principal de I'association à long terme est de développer son indépendance par rapport à I'ONG ReefDoctor et sa capacité à gérer indépendamment les ressources marines de la baie de Ranobe dont les communautés locales dépendent pour leur survie.

KEYWORDS: Conservation, reef, coral, sustainable development.

MOTS CLEF : conservation, récif, corail, développement durable. 


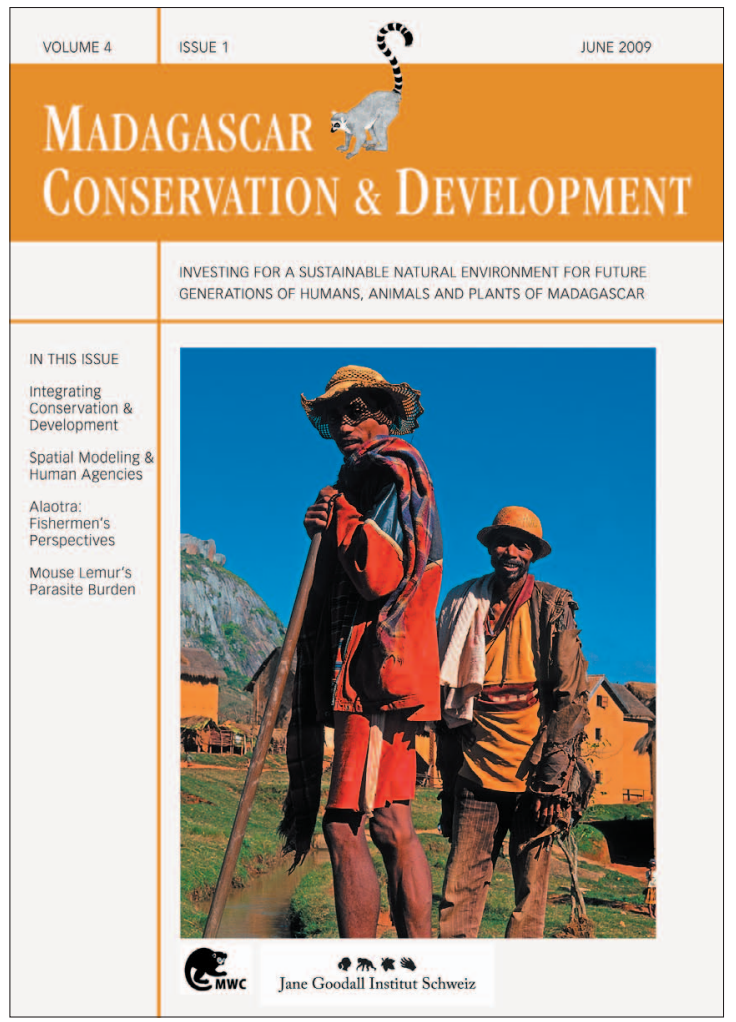

Madagascar Conservation \& Development is the journal of Madagascar Wildlife Conservation (MWC) and the Jane Goodall Institute (JGI Switzerland). It is produced in these institutions' own responsibility.

All the Issues and articles are freely available at http://www.mwc-info.net/en/services/journal.htm

Contact Journal MCD

info@journalmcd.net for general inquiries MCD funding@journalmcd.net for supporting the journal

Journal Madagascar Conservation \& Development Institute and Museum of Anthropology University of Zurich

Winterthurerstrasse 190

$\mathrm{CH}-8057$ Zurich, Switzerland

contact@mwc-info.net for general inquiries

Postfach 2701

CH-8021 Zürich, Switzerland

Logement 11, Cité Andohaniato Antananarivo 101, Madagascar

info@janegoodall.ch for general inquiries JGI

$2 \pi \approx$

Jane Goodall Institut Schweiz
Jane Goodall Institute Schweiz

Postfach 2807

8033 Zürich

Switzerland 


\section{INTRODUCTION}

The Bay of Ranobe is situated in the region of Toliara, in southwest Madagascar. A $32 \mathrm{~km}$ long reef encloses it; the lagoon is eight kilometers at its widest point and contains patch reefs, seagrass beds and an estuarine mangrove to the north and a fragmented curtain mangrove in the south. There are two rivers on each side of the Bay, the Fiherenana to the south and Manombo to the north. The Bay is situated in one of the poorest regions of Madagascar, which is one of the poorest countries in the world (World Bank 2007), and faces increasing anthropogenic caused pressures. In addition, the local population heavily depends on the natural resources provided by these reefs for their livelihoods (Davies et al. In press).

The Massif des Roses is a patch reef within the Bay of Ranobe (Figure 1). The reef is covering an area of approximately $100 \mathrm{~m} \times 160 \mathrm{~m}$ with a depth between two and seven metres. The name of the site comes from the form of foliose corals, which are widespread at the site (in particular Montipora aequituberculata). Since 25 May 2007, the Massif des Roses has been recognised as a community managed reserve under a temporary protection status by the Direction Régionale du Développement Rural (Ministère de l'Agriculture, de l'Elevage et de la Pêche). The protected site also includes seagrass beds and sand surrounding the coral patch. Seagrass constitutes a vital component of coastal ecosystems due to its primary productivity and function as nursery and shelter for fish and large invertebrates (Edgar et al. 2001). These marine habitats provide a natural buffer zone around the corals and make the Massif des Roses an ecologically diverse site.

The Massif des Roses is protected from heavy seas by the barrier reef (Figure 1). The site is situated about two kilometers from the village of Mangily and is therefore easily accessible by pirogues (out rigger canoes) or powerboats; its shallow depth makes it suitable for both snorkelling and diving. However, the

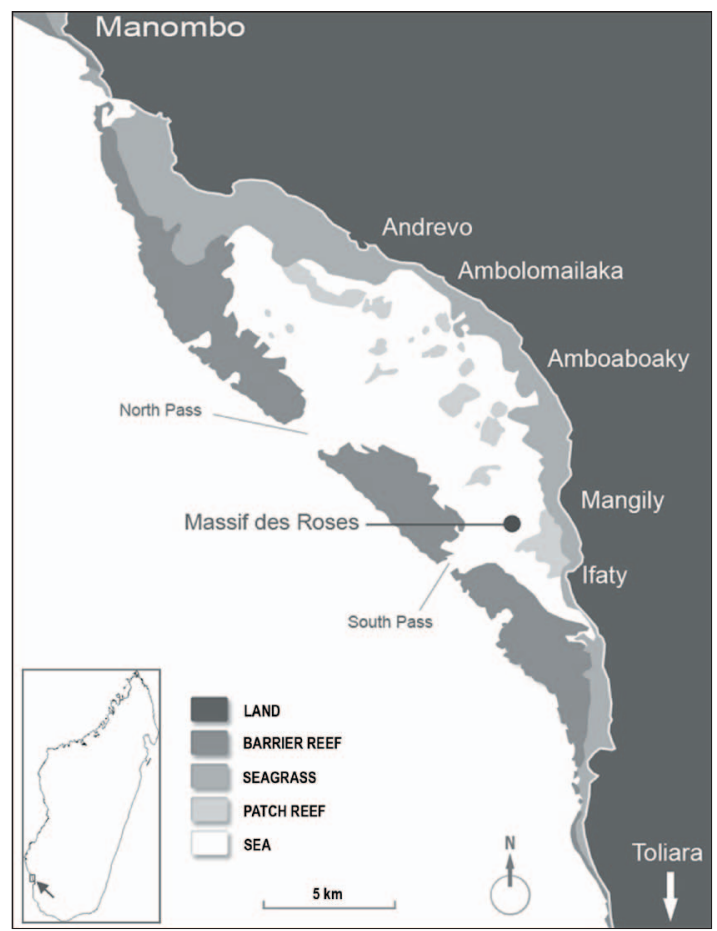

FIGURE 1. The Bay of Ranobe $\left(\mathrm{E} 43^{\circ} 30^{\prime}, \mathrm{S} 23^{\circ} 00^{\prime}, \mathrm{E} 43^{\circ} 38^{\prime}, \mathrm{S} 23^{\circ} 18^{\prime}\right)$ is protected by a $32 \mathrm{~km}$ long reef. This reef is part of the fourth largest coral reef system in the world that extends from Morombe in the north, to Toliara in the south.
Massif des Roses, like the rest of the Bay of Ranobe faces a variety of anthropogenic pressures.

TOURISM PRESSURES: The tourism industry provides a major source of income for the Toliara region, and depends to a large extent on a healthy reef, which should provide an economic incentive to protect it. However, as in many places, tourism in the Toliara region is both an asset and a threat. Some of the pressures directly or indirectly caused by tourism include: Destructive anchorage due to the lack of appropriate mooring lines, physical contact with the reef, demand from the hotels for seafood, pollution from hotels due to the lack of sewage facilities, and the curio trade involving the collection and sale to tourists of marine organisms such as shells and starfish.

FISHERIES PRESSURES: The villages along the Bay are inhabited predominantly by Vezo fishermen, who depend almost exclusively on marine resources for food and income. Nearly $50 \%$ of all Malagasy sea fishermen operate in the Toliara region (Laroche and Ramananarivo 1995), and as early as 1988, vasseur et al. reported a decrease in the abundance and size of fish and increased damage to the reef flat. Overfishing and destructive fishing methods are some major causes of coral reef degradation and are often associated with poverty and coastal crowding (McManus 1997). The population along the coast is growing at a fast rate as is generally the case in Madagascar (3\% nationally on average) (World Bank 2007), which contributes to increased fishing pressure on the reef. In addition, migrants from inland areas drawn to the site by its fishing reputation have often adopted, due to their lack of fishing tradition, destructive fishing methods, such as beach seine fishing with small mesh nets (Gabrié et al. 2000). Overfishing not only directly reduces fish numbers, but also impacts coral reef health by removing herbivorous fish species, resulting in overgrowth of algae, which can result in a phase shift of the ecosystem from coral to algae (McManus et al. 2000).

SEDIMENTATION AND POLLUTION PRESSURES:

Coral reefs are also affected by activities in their terrestrial drainage basins. Urbanisation and the intensification of land use can increase the run-off of sediment, nutrients and pollutants which may adversely affect coral reefs and their associated organisms (Grigg and Dollar 1990). It is also known that anthropogenic nutrient enrichment has a greater effect on coral reefs closer to shore and within lagoons (Szmant 2002), like the Bay of Ranobe. The fact that there are no sewage treatment facilities neither in the city of Toliara, nor in the growing villages along the coast, adds to this problem.

Deforestation is considered to be a significant threat to the Bay of Ranobe reef system. The destruction of forests for agriculture, fuel and construction leaves the exposed soil vulnerable to large-scale erosion. The Fiherenana and Manombo rivers flanking each side of the Bay carry large quantities of sediments into the lagoon. High sediment concentrations are a serious threat to corals as they reduce light penetration, thereby affecting photosynthesis of symbiotic algae zooxanthellae. As a consequence, fleshy macro algae outcompete coral in the presence of excess nutrient-rich organic terrestrial sediment (Umar et al. 1998). Healthy mangroves moderate the sediment problem, acting as a natural filter trapping sediment and nutrients (Bouillon et al. 2004). However, much of the mangrove habitat has been lost through deforestation for use as firewood, like in many other places in Madagascar (Dave 2006). 
As a result of anthropogenic activities, the reefs may show reduced resilience and be more easily affected and possibly degraded by disturbances such as storms, temperature increases and changes in sea level (Moberg and Folke 1999). As early as the 1960s scientists studying the coral reefs of the region of Toliara (see Thomassin 1971 for a review) observed an increase in the threats to the ecosystem, and noted particular concern about damaging human pressures (Vasseur 1988). In recent years both villagers and tourist operators (e.g. dive clubs and hotels) have become increasingly aware of pressures and their impact on the reef, especially within the lagoon, and are beginning to understand the need to protect the remaining healthy sites, such as the Massif des Roses.

The Massif des Roses has had informal protection for nearly a decade after tourist operators persuaded the mayors of Ifaty and Mangily (Figure 1) that it was in their mutual interest to protect it from fishing. However, the informal protection of the site had only limited success; fishermen saw little benefit in not fishing one of the lagoon's best sites, and tourist operators such as pirogue owners continued to damage the coral by dropping anchor, unaware of the agreement or the impact they were having. Even when transgression was observed and reported to the village mayors, culprits received no more than a warning. As a result, friction and mistrust grew between tourist operators and fishing community, which further deteriorated their relationship (Mayor of Ifaty, pers. com.).

Finally, the establishment of the Massif des Roses community protected site is in line with the commitment of the Malagasy Government to expand the coverage of protected areas in the country as set out in the National Environmental Action Plan. This programme aims to prioritise marine and coastal ecosystem management and more than triple the nation's coastal and marine protected areas within a period of five years (Gouvernement de Madagascar 2007).

The objective of this article is to describe the approach taken by ReefDoctor to legally protect the Massif des Roses marine reserve. We explain the establishment of the local association FIMIHARA and its role in setting up and managing the site and the development of other conservation and community initiatives in the Bay of Ranobe. We also highlight the challenges faced in putting this approach into practice to inform the adoption of similar approaches elsewhere in Madagascar and perhaps beyond.

\section{IMPLEMENTING THE MARINE RESERVE MASSIF DES ROSES}

The NGO ReefDoctor has been working in the Bay of Ranobe since 2002, carrying out research, conservation and education programmes. In particular, it has carried out a number of socio-economic projects including raising local environmental awareness, school restoration and marine education, alternative livelihoods initiatives for villagers such as marketing honey and toy pirogues, and the promotion of solar oven use to reduce deforestation. These community projects helped the NGO win the support and trust of local people and provided examples of the type of work that could later be funded through income from the Massif des Roses protected site. In addition, ReefDoctor conducted a preliminary socio-economic survey of the traditional fishery of the Bay focusing on the villages of Ifaty, Mangily and Beravy, the results of which are discussed in detail in Davies et al. (In press). The main finding of this study was that the fishery was heavily exploited with a predominance of small fish in catches, especially when beach seines were used. This reinforced the need for protection of the bay's resources, ideally with strong community involvement.

In October 2006, ReefDoctor organised a first meeting with fishermen from Mangily and Ifaty to discuss the protection of the Massif des Roses. The fishermen were enthusiastic and agreed to form an association with elected representatives to work with ReefDoctor. The association was called 'FI.MI.HA.RA' (FIkambanana Mlaro sy HAnasoa ny RAnomasina - Association to Protect and Enhance the Marine Environment).

The association FIMIHARA was legally recognised on 11 April 2007 and a dina (local law) was adopted for the protection of the site. In contrast with the previous initiatives in the Bay of Ranobe, which were imposed upon the locals, the ReefDoctor initiative was adopted by the local community itself and incorporated into their local legal system. The legalization of the dina is a long process, which is still being carried out. Dina have a strong authority at the community level and have already been applied in Madagascar to protect marine areas (Rakotoson and Tanner 2006, Harris 2007). ReefDoctor drew in particular on the example of Nosy Ve island south of Toliara, where a community association (FIMIMANO) was created in 1998 to resolve conflict over the island's natural resources. A dina was adopted to establish regulations governing a community managed marine reserve (Rakotoson and Tanner 2006). This association is made of representatives from all the villages in the area that depend on Nosy Ve for its resources. On the advice of the Toliara branch of SAGE (Service d'Appui à la Gestion de I'Environnement), and based on their experience with FIMIMANO, the representation of the FIMIHARA association was subsequently extended to all villages of the Bay of Ranobe. The structuring of the association and the necessity to include neighbouring villages were presented at a public meeting of local and regional stakeholders organised by ReefDoctor in November 2006. More than a hundred people attended, representing all key stakeholder groups. However, only two representatives of the tourism industry were present, reflecting the limited success at this stage in engaging them in the project.

The FIMIHARA bureau (or committee) consists of a president, two vice presidents, a treasurer, two secretaries, two accountants, 16 advisers and 20 active members (as of December 2008). The active members elect all committee members; active members pay an annual membership fee of 2,000 Ariary ( $€$ 0.75) and committee member pay 4,000 Ariary ( $€$ 1.50). FIMIHARA members meet every two months to discuss their activities. The association has the following stated objectives:

- $\quad$ Provide a voice for all stakeholders who have an interest in the future of the bay.

- Improve the quality of life of those who live and work along the Bay of Ranobe.

- Work to conserve marine and terrestrial natural resources for future generations.

- Improve knowledge and understanding of the natural environment.

- $\quad$ Provide guidance in managing the community-run marine reserve Massif des Roses. 
Table 1 outlines the main role of each stakeholder group and their specific involvement in the FIMIHARA association and the protection of the Massif des Roses.

The association is responsible for overseeing the site, including the employment of a site guardian and collecting revenue from ticket sales and fines; funds generated are used for community projects as identified by FIMIHARA In support of FIMIHARA, ReefDoctor provides finance, advice, and administrative support such as recording meetings and setting up a bank account.

The association FIMIHARA has the authority to manage the newly created marine reserve, including its financial management. The Massif des Roses and surrounding area covering a total of 1.6 ha $(100 \mathrm{~m} \times 160 \mathrm{~m})$ has been recognised as a community managed reserve under temporary protection since 25 May 2007 by the Direction Régionale du Développement Rural (Ministère de I'Agriculture, de l'Élevage et de la Pêche), which entails that:

- $\quad$ Fishing is banned within the protected site marked with buoys. Infractions are punishable by fines enforced and collected by FIMIHARA via an on site guardian.

- Dropping anchor is forbidden throughout the protected site; visiting boats must moor to buoys already in place for this purpose within the site, at the edge of the coral. Infractions are punishable by fines.

- $\quad$ The theft of materials from the site such as marking and mooring buoys is punishable by fines.

TABLE 1. Outline of the involvement of each stakeholders in the development of the FIMIHARA association and the Massif des Roses protection.

\begin{tabular}{|c|c|}
\hline STAKEHOLDER GROUP & INVOLVEMENT IN FIMIHARA \\
\hline \multicolumn{2}{|l|}{ Local People } \\
\hline \multirow[t]{3}{*}{ Fishermen and other inhabitants of the bay } & Representation on FIMIHARA committee \\
\hline & $\begin{array}{l}\text { Empowered to manage their own marine resources and encouraged to adhere to the laws to } \\
\text { protect the Massif des Roses }\end{array}$ \\
\hline & Representative (village mayors) commented on draft laws (dina). \\
\hline \multicolumn{2}{|l|}{ Research and Conservation Organisations } \\
\hline \multirow[t]{3}{*}{ ReefDoctor NGO } & Research, education and conservation initiatives in the Bay of Ranobe \\
\hline & Main actor in the establishment of FIMIHARA and the protection of the site \\
\hline & Main adviser to FIMIHARA \\
\hline \multirow[t]{3}{*}{ Service d'Appui Gestion de I'Environnement (SAGE) } & $\begin{array}{l}\text { Prepared EP3 (Environmental Program 3) as part of the UN Environmental Action Plan for } \\
\text { Madagascar }\end{array}$ \\
\hline & $\begin{array}{l}\text { Advised on laws (dina) and set up of FIMIHARA based on experience of similar association } \\
\text { FIMINANO at Anakao. }\end{array}$ \\
\hline & Advisory members of FIMIHARA committee \\
\hline $\begin{array}{l}\text { Institut Halieutique et des Sciences Marines (IHSM), } \\
\text { University of Toliara }\end{array}$ & Research and education on the Bay of Ranobe \\
\hline \multicolumn{2}{|l|}{ Private Sector (Tourism) } \\
\hline \multirow{4}{*}{$\begin{array}{l}\text { Hoteliers and dive centres } \\
\text { (represented by the association of hoteliers and the Office } \\
\text { Régional du Tourisme de Tuléar, ORTU) }\end{array}$} & Sell Massif des Roses entry tickets to tourists \\
\hline & $\begin{array}{l}\text { Promotion of protection of Massif des Roses to tourists e.g. by display of environmental } \\
\text { information material }\end{array}$ \\
\hline & Comment by a representative on drafts of laws (dina) \\
\hline & Representation on FIMIHARA committee \\
\hline \multirow[t]{3}{*}{ Pirogue owners } & Promote the site to tourists \\
\hline & Site visits for tourists \\
\hline & Members of FIMIHARA association \\
\hline \multirow[t]{2}{*}{ Tourists } & Pay site visit entry fee to FIMIHARA \\
\hline & $\begin{array}{l}\text { Awareness of site and broader marine conservation issues through visits to site and } \\
\text { FIMIHARA environmental information material. }\end{array}$ \\
\hline \multicolumn{2}{|l|}{ Regional and Local Government } \\
\hline \multirow{2}{*}{$\begin{array}{l}\text { Communes (Belalanda and Manombo): Mayors / Deputy } \\
\text { Mayors }\end{array}$} & Signed off local laws to establish FIMIHARA and protect Massif des Roses \\
\hline & Members of FIMIHARA association \\
\hline \multirow{4}{*}{$\begin{array}{l}\text { Fokontany / Quartier } \\
\text { (Administrative units of one or more villages) }\end{array}$} & Consulted on draft laws \\
\hline & Signed off local laws to establish FIMIHARA \\
\hline & Represent local people on FIMIHARA committee \\
\hline & Members of FIMIHARA committee \\
\hline \multirow{3}{*}{$\begin{array}{l}\text { Region (Toliara): } \\
\text { Direction Régionale du Développement Rural (DRDR) } \\
\text { Ministère l'Agriculture, de l'Elevage et de la Pêche }\end{array}$} & Consulted on draft laws \\
\hline & Signed off local laws (dina) to establish FIMIHARA and protect Massif des Roses \\
\hline & Members of FIMIHARA association \\
\hline \multirow{2}{*}{$\begin{array}{l}\text { Chief of district and chief of Police, Toliara } \\
\text { Ministère des Eaux et Forêts }\end{array}$} & Signed off local laws to establish FIMIHARA \\
\hline & Officially legalised the status of the organisation \\
\hline
\end{tabular}


- Tourists who visit the site must pay an entry fee of 2,000 Ariary (€ 0.75)

- A guardian is on site daily to collect tickets and ensure compliance with the law.

- $\quad$ Funds generated from ticket sales and fines are used for community projects as identified by FIMIHARA for the villages of the Bay of Ranobe.

To raise awareness of FIMIHARA's role and authority and build support for the project considerable effort was made to engage local stakeholders. Various means were employed including canvassing Regional Government representatives, organising meetings in all 13 villages along the Bay of Ranobe, creating multilingual publicity material, and visiting all tourist industry representatives including hotels, dive clubs and the regional tourism office, ORTU (Office Régional du Tourisme de Tuléar).

\section{DISCUSSION}

Experience has shown that traditional top-down approaches to protected areas are often not effective in achieving conservation objectives and are not sustainable in the longterm; they alienate local resource users and are often perceived as a drain on the resources by the local populations (Brown 2000). Furthermore, protected areas have often negatively affected many indigenous people in Africa (Newmark and Hough 2000). Integrated conservation and development projects now aim at equally focusing on biological conservation and human development (Alpert 1996) and are seen as a means to develop supportive relationships with the communities (Newmark and Hough 2000) by involving them in the conservation project. This concept has been successful at building capacity for conservation amongst local communities, although a period of about a decade was often necessary to observe positive results (Baral et al. 2007).

A failure to engage all interested parties in decisionmaking can be attributed to the limited success of initial attempts to protect the Massif des Roses. Here the active stakeholder participation, particularly local people, through the association FIMIHARA, rendered it a community-managed project, which is key to its sustainability.

More and more community-based approaches are being implemented in Madagascar (Rakotoson and Tanner 2006, Harris 2007, Watson et al. 2007) and throughout the world (see for example Johannes 2002, Balgos 2005, McClanahan et al. 2006). A review of 25 years of communitybased projects for the conservation of coral reefs in the Philippines concluded that community participation and cooperation of all interested parties are essential for sustainable reef management (White and Vogt 2000). A recent review of the management of marine protected areas (MPA) in eastern Africa also suggested that the involvement of local communities who depend on the sites on a daily basis is essential to ensure long-lasting results (Francis et al. 2002). Finally, Beger et al. (2004) reviewed the effectiveness of communitybased marine reserves and concluded that for such projects to be successful, the following conditions are necessary: An efficient surveillance of the site, ongoing advice from the organisation that facilitated the establishment of the reserves and the rapid realisation of tangible benefits for local people.
AN INITIAL ASSESSMENT. At the end of 2008, the marine reserve has been in operation for 18 months. During this time more than 1,500 tickets have been sold resulting in a net benefit of over $€ 1,000$, some of which has already been used for community projects. As expected, the site entry fee of less than $€ 1$ has been readily accepted by tourists on the understanding that it contributes to funding community projects and ensures the site protection. Villagers are still in the process of submitting short proposals for community projects to the association. So far the funds generated have been mainly used for the maintenance of the Massif des Roses site, but also allowed to pay for sanitation workers in Ifaty, to make a small contribution to the opening of a local clinic in Ambolimailaka and to the refurbishment of a middle school in Mangily, and to fund a small portion of the costs associated with the opening ceremony of new marine reserves and No Take Zones (see below). Importantly, more than a year after its creation, all key stakeholders continue to be supportive of the project. Notably, dive centres are now working more closely with FIMIHARA and ReefDoctor and have been particularly helpful with the initial set up and maintenance of the site.

The presence of a guardian clearly acts as a strong reinforcement of the dina in particular with regard to fishing and anchoring and ensuring entrance fee payment. There has been only one known instance of transgression of the laws. In February 2008, three pirogue fishermen were reportedly caught fishing with nets on the site; a fine was successfully imposed.

CHALLENGES AND LESSONS LEARNED. Although the

Massif des Roses marine reserve proved to be a clear success in terms of its popularity with tourists with more than a thousand tickets sold in 18 months, the FIMIHARA association has also faced a number of problems over its first two years of existence. Convincing local people that the intention of FIMIHARA was to provide local benefit proved difficult, but was facilitated by the NGO's Malagasy local staff. It is a continuous challenge to steer the aspirations of some committee members away from a fisheries focus and towards sustainable resources management. ReefDoctor continues to advise FIMIHARA, but with the long-term aim of enabling the association to operate independently. A challenge for FIMIHARA in achieving its objectives is that it lacks full support from some parts of the community it represents; it is regarded by some as benefiting a small closed group of people only rather than the wider community. Concerns have been encouraged by an initial lack of transparency in accounting, and perception of weak leadership.

Because ReefDoctor played such a pivotal role in setting up the association and in providing advice on its management there have been some misunderstandings about roles and responsibilities. There is an ongoing need to reinforce the fact that FIMIHARA is a local association, assisted by the NGO but managed and run by local representatives. In addition, it has been difficult for the association to find capable, trustworthy and motivated staff; there have been instances with previous guardians fishing in the reserve and pocketing entrance fees.

The fact that the association was initially meant to include only the villages of Ifaty and Mangily (Figure 1) has sometimes led to a feeling of disenfranchisement in other villages. In order to counteract this perception of unequal engagement and benefit, it was decided that for the next elections of the FIMIHARA committee, each region of the Bay (southern, central and northern) would present two candidates for president; the 
elected president would then be joined by two vice-presidents, each coming from a different area of the bay.

Finally, FIMIHARA still relies heavily on ReefDoctor for its operation. The NGO's budget is currently between 15 and 20 million Ariary (between $€ 5,600$ and $€ 7,500$ ) a month to cover operational costs. We believe that the replication of such project elsewhere would require similar ongoing financial commitment. The approach is likely to be difficult for local communities without external funding. ReefDoctor aims to continue capacity building over the next few years, including for instance, workshops on simple accounting, profit monitoring and public relations.

LONG-TERM ENGAGEMENT. The long-term goal is to

continue to protect the Massif des Roses from further damage and to allow its biodiversity to recover, although it is too early yet to assess ecological improvements due to site protection. However, to measure the impact of marine reserves on the conservation of biological diversity, ReefDoctor has set up a bi-annual biodiversity monitoring programme by means of underwater survey transects to allow the comparison of protected reserves and other sites both within and outside the lagoon. These monitoring results will allow for comparison of current marine ecological state of the Bay with older survey data sets (e.g. Thomassin 1971). As the scope of work of FIMIHARA broadens within the bay, the representation of the stakeholder interests is regularly reviewed on a two months-basis during FIMIHARA meetings. More and more responsibility and political power is handed over to other villages outside Ifaty and Mangily.

The Massif des Roses's earlier informal protection and tourist interest clearly facilitated the establishing of a marine reserve. The establishment of similar reserves in other sites lacking such history may prove more challenging. Also, the long-term sustainable protection of the Massif des Roses is not guaranteed by its protection status alone. Ongoing participative, effective and transparent operational management is important if Massif des Roses is to provide a model for similar projects elsewhere, not least within the Bay of Ranobe.

As part of the long-term plan to protect additional sites within the Bay of Ranobe, on the 1 December 2008, three more locally recognised marine reserves were established at the following locations: Ankarandjelita in the north, Ankarabory which is situated to the northwest of the Massif des Roses and Andabotira in the south. In addition, six temporarily protected octopus fishery areas (No Take Zone, NTZ) have been closed for fishing for six months. A similar initiative was carried out in Anda-

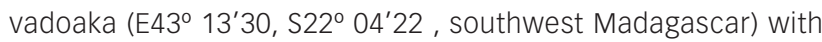
the creation of a network of community-run protected areas set up by the British NGO Blue Ventures; however, insufficient NTZ were closed at the same time, which resulted in over-harvesting on reopening (Harris 2007). In the Bay of Ranobe, we hope that the simultaneous closure of six discrete and widely separated areas will counteract similar problems and improve the sustainability of the octopus fishery.

FUTURE PROJECTS. As well as seeking to work collaboratively with conservation bodies, FIMIHARA and ReefDoctor have received funds from the United Nations Development Programme Small Grants Project for the following projects to be implemented within the Bay of Ranobe: The creation of artificial reefs outside the lagoon using fish aggregation devices, the restoration of mangroves, and a programme of fishing gear exchange whereby destructive equipment such as beach seine nets are exchanged for gill nets of larger mesh size. Future planned FIMIHARA projects include the introduction of restrictions on the use of damaging fishing equipment, setting up an association of pirogue tourist operators, the development of artisanal products such as handicrafts and ecotourism employing marine guides for the Marine Protected Areas.

The sustainable conservation of the Massif the Roses is important for the communities who live in the Bay of Ranobe and depend almost exclusively on its resources for their livelihood (Davies et al. In press). Long-term success to sustainably manage, conserve and possibly restore the Bay of Ranobe in order to build resilience to climate change and other pressures will depend on the development of local governance and capacity building such as strengthening internal governance, developing external communications and encouraging better transparency in accounting. The association therefore remains the basis on which to build further sustainable resource management initiatives such as the new marine reserves and NTZs established in 2008.

\section{CONCLUSION}

Our study shows that all stakeholders' interests need to be taken into account for an efficient ecological protection of a site, which requires a careful balancing of all the values and factors involved: Local people and their respective cultures, community politics, fisheries and other livelihoods, ecological needs and tourism. FIMIHARA has played an essential role in the establishment and operation of the Massif de Roses and, more importantly, in empowering and engaging the communities of the Bay of Ranobe. The association will now be crucial to assure long-term local protection of the Massif des Roses and success of subsequent projects. To this end, it is important that FIMIHARA increasingly takes the lead in managing the marine resources of the Bay of Ranobe.

\section{ACKNOWLEDGEMENTS}

We would first like to thank all staff and volunteers of ReefDoctor, including and in particular our local staff. We would especially like to thank Nome Beanjara for his help in setting up FIMIHARA and Thomas Wadsworth for the design of the Bay of Ranobe map. We are especially grateful to Bruno (mayor of Ifaty) for the useful information he provided. We also thank M. Man Wai (director of the IHSM) for administrative support, as well as the Toliara branch of SAGE (Ananias in particular) for advice on setting up FIMIHARA, and the dive clubs of Ifaty and Mangily for helping to build and place the marker and mooring buoys of the marine reserves (in particular Richard from Le Grand Bleu). We are also grateful to the Malagasy authorities, in particular Dr. Edaly (Direction Régionale du Développement Rural), Christophe Rabenvanana (Ministère de l'Agriculture, de l'Élevage et de la Pêche) and Hervé (Préfecture de Tuléar) for the legalization of the association and marine reserve.

\section{REFERENCES}

Alpert, P. 1996. Integrated conservation and development projects. Bioscience 46, 11: 845-855.

Balgos, M. C. 2005. Integrated coastal management and marine protected areas in the Philippines: Concurrent developments. Ocean and Coastal Management 48, 11-12: 972-995. (doi:10.1016/ j.ocecoaman.2005.03.003) 
Baral, N., Stern, M. J. and Heinen, J. T. 2007. Integrated conservation and development project life cycles in the Annapurna Conservation Area, Nepal: Is development overpowering conservation? Biodiversity and Conservation 16, 10: 2903-2917. (doi:10.1007/s10531-006-9143-5)

Beger, M., Harborne, A. R., Dacles, T. P., Solandt, J.-L. and Ledesma, G. L. 2004. A framework of lessons learned from community-based marine reserves and its effectiveness in guiding a new coastal management initiative in the Philippines. Environmental Management 34, 6: 786-801. (doi:10.1007/s00267-004-0149-z)

Bouillon, S., Moens, T. and Dehairs, F. 2004. Carbon sources supporting benthic mineralization in mangrove and adjacent seagrass sediments (Gazi Bay, Kenya). Biogeosciences 1, 1: 71-78.

Brown, K. 2002. Innovations for conservation and development. The Geographical Journal 168, 1: 6-17.

Dave, R. 2006. Mangrove ecosystems of southwest Madagascar: An ecological human impact, and subsistence value assessment. Tropical Resources Bulletin 25: 7-13.

Davies, T. E., Beanjara, N. and Tregenza, T. In Press. A socio-economic perspective on gear based management in an artisanal fishery in South West Madagascar. Fisheries Management and Ecology.

Edgar, G. J., Mukai, H. and Orth, R. J. 2001. Fish, crabs, shrimps and other large mobile epibenthos: Measurement methods for their biomass and abundance in seagrass. In: Global Seagrass Research Methods. F. T. Short and R.G. Coles (eds.), pp 255-270. Elsevier, Amsterdam.

Francis, J., Nilsson, A. and Waruinge D. 2002. Marine protected areas in the eastern African region: How successful are they? Ambio 31, 7-8: 503-511.

Gabrié, C., Vasseur, P., Randriamiarana, H., Maharavo, J., and Mara, E. 2000 The coral reefs of Madagascar. In: Coral Reefs of the Indian Ocean: Their Ecology and Conservation. T. R. McLanahan, C. R. C. Sheppard, and D. O. Obura (eds.), pp 411-444. Oxford University Press.

Gouvernement de Madagascar. 2007. Madagascar Environnemental Action Plan. <http://www.madagasca.gov.mg/MAP> accessed on 10 December 2008.

Grigg, R. W. and Dollar, S. J. 1990. Natural and anthropogenic disturbance on coral reefs. In: Ecosystems of the World 25: Coral Reefs. Z. Dubinsky (ed.), pp 439-451. Elsevier, Oxford.

Harris, A. 2007. "To live with the sea": Development of the Velondriake community-managed protected area network, southwest Madagascar. Madagascar Conservation \& Development 2, 1: 43-49.

Johannes, R. E. 2002. The renaissance of community-based marine resource management in Oceania. Annual Review of Ecology and Systematics 33: 317-340. (doi:10.1146/annurev.ecolsys.33.010802.150524)

Laroche, J. and Ramananarivo, N. 1995. A preliminary survey of the artisanal fishery on coral reefs of the Tulear region (southwest Madagascar). Coral Reefs 14, 4: 193-200. (doi:10.1007/BF00334341)

Mcclanahan, T. R., Marnane, M. J., Cinner, J. E. and Kiene, W. E. 2006. A comparison of marine protected areas and alternative approaches to coral-reef management. Current Biology 16, 14: 1408-1413. (doi:10.1016/j.cub.2006.05.062)

McManus, J. W. 1997. Tropical marine fisheries and the future of coral reefs: a brief review with emphasis on Southeast Asia. Coral Reefs 16: S121S127.

McManus, J. W., Menez, L. A. B., Kesner-Reyes, K. N., Vergara, S. G. and Ablan, M. C. 2000. Coral reef fishing and coral-algal shifts: Implications for global reef status. ICES Journal of Marine Science 57, 3: 572-578. (doi:10.1006/jmsc.2000.0720)

Moberg, F. and Folke, C. 1999. Ecological goods and services of coral reef ecosystems. Ecological Economics 29, 2: 215-233. (doi:10.1016/S09218009(99)00009-9)

Newmark, W. D. and Hough, J. L. 2000. Conserving wildlife in Africa: Integrated conservation and development projects and beyond. Bioscience 50, 7: 585-592. (doi:10.1641/0006-3568(2000)050[0585: CWIAIC]2.0.CO;2)

Rakotoson, L. R. and Tanner K. 2006. Community-based governance of coastal zone and marine resources in Madagascar. Ocean and Coastal Management 49, 11: 855-872. (doi:10.1016/j.ocecoaman.2006.08.003)
Szmant, A. M. 2002. Nutrient enrichment on coral reefs: Is it a major cause of coral reef decline? Estuaries and Coasts 25, 4: 743-766. (doi:10.1007/BF02804903)

Thomassin, B. A. 1971. Revue bibliographique des travaux de la station marine de Tuléar (République Malgache) 1961-1970. Tethys suppl. 1: 3-50.

Umar, M. J., McCook, L. J. and Price, I. R. 1998. Effects of sediment deposition on the seaweed Sargassum on a fringing coral reef. Coral Reefs 17, 2: 169-177. (doi:10.1007/s003380050111)

Vasseur, P., Gabrié, C. and Harmelin-Vivien, M. 1988. State of coral reefs and mangroves in the Tuléar region (SW Madagascar): Assessment of human activities and suggestions for management. Proceedings $6^{\text {th }}$ International Coral Reef Symposium, Townville 2: 421-426.

Watson, R. T., René de Roland L. A., Rabearivony J. and Thorstrom, R. 2007. Community-based wetland conservation protects endangered species in Madagascar: Lessons from science and conservation. Banwa 4: 83-97.

White, A. T. and Vogt, H. P. 2000. Philippine coral reefs under threat: Lessons learned after 25 years of community-based reef conservation. Marine Pollution Bulletin 40, 6: 537-550. (doi:10.1016/S0025-326X(99)00243-X)

World Bank. 2007. Data and Research. Key development data and statistics. 2007. <http://www.worldbank.org> accessed on 10 December 2008. 